Tibor Navracsics

\title{
EUROPEANISATION OR SIMPLY INSTITUTIONAL CHANGE? THE IMPACT OF THE EU MEMBERSHIP ON THE POLITY OF HUNGARY
}

Tibor Navracsics, PhD, Senior Research Fellow, Head of Institute, Europe Strategy

Research Institute, Eötvös József Research Centre, University of Public Service, navracsics.tibor@uni-nke.hu

The European integration has had a major impact on the institutional systems of the Member States. The case study traces some of the characteristics of the institutional changes brought about by EU-membership through the example of Hungary. The study concludes that rather than being subject to Europeanisation, there has been an institutional adaptation in the government's handling of European affairs in Hungary over the last 20 years. It also affirms, that close policy cooperation does not automatically lead to a single institutional model at EU level.

KeYwORDS:

case study, enlargement, Europeanisation, European Union, Hungary 


\section{ENLARGEMENT AND EUROPEANISATION}

No one disputes today that European integration has had a major impact on the institutional systems of the Member States. Many see the European integration as a statebuilding process, and as such they look for signs that will lead to a single European institutional setup. Others expect the superiority of the European approaches to modernise their own country's institutional system and heal its deficiencies.

While there is a consensus that European integration has an impact on the political system of the member states, it remains debatable how this effect can actually be described. According to intergovernmental theories, the process of European integration does not weaken the Member States. Nation states remain the masters of European integration, and European integration itself not only does not weaken European states, but actually saves them. ${ }^{1}$

Proponents of neofunctionalism and multi-level governance believe that nation states are being increasingly affected by integration and that their political and institutional systems are increasingly becoming a common 'European' system. ${ }^{2}$ It is this interpretation that can determine how exactly to describe the impact of ever-closer international cooperation at the European Community level on the Member States. While this impact clearly affects the area of policy cooperation, the process is much more contentious with regard to polity. The process of unification in policies is much less pronounced or completely absent: the institutional system of the Member States of the European Union is as heterogeneous as it was 50 years ago.

Nevertheless, the debate on the Europeanisation of the institutional systems of Member States has been one of the defining elements of the literature on the European Union for many years. Although Johan P Olsen stated as early as 2002 that the concept itself was unsuitable for explaining certain phenomena, ${ }^{3}$ for many today, twenty years later, Europeanisation is still synonymous with European integration. While it may not be expected to have explanatory power, the ideology of the concept remains influential. Since the mid-1990s, Europeanisation has often been interpreted in a normative sense. This conception was primarily referred to at the time of the accession of Central and Eastern European countries. In this sense, Europeanisation means improving the quality of the political system. It represents a model of institutional transformation, in which the accession countries of Central and Eastern Europe adopt institutional approaches from the countries of Western Europe and from the European Union itself, thereby improving the quality of their own political systems.

Alan Milward, The European Rescue of the Nation-State (Berkeley - Los Angeles: University of California Press, 1992).

2 Ernst B Haas, The Uniting of Europe: Political, Social and Economic Forces 1950-1957 (Stanford: Stanford University Press, $2^{\text {nd }}$ edition, 1968).

3 Johan P Olsen, 'The Many Faces of Europeanization', Journal of Common Market Studies 40, no 5 (2002), 921952. 
The political context for this interpretation was provided by the Copenhagen criteria adopted by the European Council in 1993. This document set political requirements specifically for the applicant countries of Central and Eastern Europe. This conditionality was extended two years later by the adoption of the Madrid criteria. New criteria were added to the previous points, in particular on the quality of democracy, requiring the applicant countries to strengthen their administrative capacities.

In this interpretation, Europeanisation is a kind of pressure on Member States to adapt to political systems. The process applies not only to the area of policies, but also, especially in the Central European and Eastern European countries, involves reorganising and 'Europeanising' the institutional system. As such, the process of Europeanisation entails the modernisation of polities while at the same time it denotes a convergence of various institutional systems into a single European polity.

For other scholars, however, European integration not only represents the process of adapting member states' institutions, but also a change in the institutional balance of domestic policy: "From this perspective, Europeanization raises the important question of how political equilibrium is altered by the mechanisms triggered by EU integration."4 They put the emphasis not on the European but on the domestic effects of Europeanisation. This implies that the input coming from the European level in the form of external pressure brings about significant change in interinstitutional relations.

Undoubtedly, there are clear signs of Europeanisation in the area of policies. One of the most visible aspects of the process of European integration is the convergence of the policies of member states and the policy system emerging at European level. At the very first steps of integration, policies provided a common framework for it to be interpreted within. In the meantime, a new outlet for member states' policies also emerged at European level. The common agricultural policy and later also other policies at European level are clear evidence that there is a convergence between policy areas, which also means uniformity in some policies.

This process is much less clear-cut with regard to institutional systems. Some observers believe that institutionalised and intensive cooperation necessarily entails the convergence and the merger of political institutions. ${ }^{5}$ Others see innovation as the most important characteristic of Europeanisation. According to this view, the most important impact of Europeanisation on the institutional system is that European integration pushes Member States to create government units that did not exist before. Examples include the establishment of a special Ministry of the Environment in Portugal or the institutional

Kevin Featherstone and Claudio M Radaelli, 'A Conversant Research Agenda', in The Politics of Europeanization, ed. by Kevin Featherstone and Claudio M Radaelli (Oxford: Oxford University Press, 2003), 338-339.

5 Dietrich Rometsch and Wolfgang Wessels, 'Conclusion: European Union and National Institutions', in The European Union and Member States: Towards Institutional Fusion? ed. by Dietrich Rometsch and Wolfgang Wessels (Manchester: Manchester University Press, 1996), 351-352. 
emergence of an overseas development policy department in the Greek government system. ${ }^{6}$

The change of the institutional balance of power through the strengthening of the executive power is another form of Europeanisation. This phenomenon appears to be universal. In all Member States, European integration has led to the executive becoming more politically visible and assertive, while national legislatures are weakening. At the same time, the impact of EU membership can restructure not only the balance of power between the branches of power, but also within them. One of the most significant signs of this internal repositioning inside the executive is the rise of the prime ministers. This development has been noteworthy even in countries where the prime minister's traditional role was simply to co-ordinate ministers. ${ }^{7}$

As these two aspects seem to be the most accepted ones in terms of the impact of the European Union on the institutional systems of the Member States, I will look at them in the two sections below on the institutional changes in the Hungarian political system. While the accession process itself has obviously had an impact on the institutional system and led to the creation of new institutions, the fundamental question for me here is whether this represents simple institutional change or adaptation, or whether it is actual Europeanisation, in the sense that the institutional change has something in common with the Member States of the European Union.

\section{GOVERNMENT-LEGISLATURE RELATIONS: CHANGING EQUILIBRIUM}

As a result of the democratic transition of 1989-1990, Hungary became a so-called chancellor's democracy, which is close to the German constitutional model. One of the fundamental features of this type of polity is that there is a very balanced relationship between the executive and the legislative power. Unusually, compared to classical parliamentary systems, the legislature has much more limited options to start motions of no-confidence and to overthrow the government. The same applies in reverse, since the government also has very limited options for disbanding the legislature and is less at the mercy of the potentially changing majority conditions in parliament. ${ }^{8}$

This institutional model has stood the test of time. Although the Hungarian Parliament adopted a new constitution in 2011, which introduced a number of novelties compared to the old one, the new constitution has perpetuated the already familiar and functioning

Hussein Kassim, 'The Europeanization of Member States Institutions', in The Member States of the European Union, ed. by Simon Bulmer and Christian Lequesne (Oxford: Oxford University Press, 2005), 291.

Andrew Moravcsik, 'Why the European Community Strengthens the State: Domestic Politics and International Cooperation', CES Working Paper no 52 (1994).

8 Hans Mommsen, 'The Origins of Chancellor Democracy and the Transformation of the German Democratic Paradigm, German Politics and Society 25, no 2 (2007), 11. 
institutional model. Consequently, the institutional setup and relations established in the first year of Hungary's democratic transition, based on a balanced relationship between the two powers, still applies to this day. Beyond the constitutional system, however, the political equilibrium is constantly changing, partly because of the informal dynamics of mutable political developments and partly because of the impact of European integration.

One of the clearest signs of a change in the political balance is the strengthening of the executive at the expense of the legislative power. ${ }^{9}$ This shift usually does not lead to constitutional change in most countries, but it can have a serious impact on the degree of cooperation between different branches of power. General experience shows, however, that the big losers of European integration are the national parliaments. ${ }^{10}$

This process is also noticeable in Hungary. Since 1990, the Hungarian constitutional system has reflected German patterns. One of the defining features of the so-called chancellor's democracy is the government's considerable independence from parliament. In European affairs, relations between the Government and Parliament were defined in 2004. The government's activities in the European Union are monitored primarily by the Committee on European Affairs. On this parliamentary committee, representatives of the government and MPs discuss current issues concerning the European Union and the government's annual briefing on EU's policies.

Ahead of European Council meetings and other political events of strategic importance at European level, the task of the Hungarian Parliament's Consultative Body on EU Affairs is to provide the Prime Minister with the opportunity to discuss the Hungarian position. The Members of the Consultative Body are the Speaker, the Heads of the Parliamentary Political Groups and the Chairs of the Committees on European Affairs, Constitutional Affairs and Foreign Affairs, respectively.

The Government is obliged to consult Parliament on all matters of legislation in EU affairs. The Parliament may participate in the process of definition of a national position on drafts at any time. At its request, the Government is obliged to make all documents and information available to Parliament. It is important to note, however, that Parliament's opinion is not binding on the Government and its own position may differ from the Government line. ${ }^{11}$

At plenary sessions of the Parliament, it is also possible to discuss issues relating to the European Union in the framework of a political debate. At this juncture, representatives of the Government, parliamentary factions and even MEPs can express their views on the subject. Although this has the potential to be one of the most efficient tools for Parliament to raise its profile in European affairs, to date the Hungarian legislature has not

John W Schiemann, 'Hungary: the emergence of chancellor democracy', The Journal of Legislative Studies 10, no 2-3 (2004), 128-141.

10 Robert Ladrech, Europeanization and National Politics (Basingstoke: Palgrave Macmillan, 2010), 27.

11 Márta Dezső and Attila Vincze, Magyar alkotmányosság az európai integrációban (Budapest: HVG-ORAC, 2006), 199-200. 
been very keen on using this instrument, according to the data, since in the seventeen years of EU membership only eleven parliamentary political debates were held in the Hungarian Parliament on the issue of European integration.

During these seventeen years of EU membership, the Hungarian Parliament has indicated twice, as part of the subsidiarity control mechanism, that an EU legal instrument poses a threat to national sovereignty. The first 'yellow card procedure' was triggered in 2013 in relation to the Commission's proposal for a Regulation establishing the European Public Prosecutor's Office. In October 2013, a majority of the Hungarian Parliament voted in accordance with Article 87/2013 (X.22.) OGY's decision, deciding that the draft regulation was in breach of the principle of subsidiarity. The other case was the Draft Posting of Workers Directive, which was announced by parliament in May 2016 in accordance with Article 9/2016 (V.10.) OGY's decision that the draft directive infringes the principle of subsidiarity.

As can be seen, the Hungarian Parliament is not a very active player in shaping Hungary's European political priorities. It is true, however, that the legal framework for the Government and Parliament supports a more consultative rather than substantive decisive role for the legislature. As a result, Hungarian public law essentially defines European affairs as a matter for the executive, which parliament prefers to participate in only on an advisory basis.

At the same time, the Parliament's subordination to the Government is further strengthened by the current political developments, in addition to the legislation. Over the last ten years, the parliamentary balance of power has clearly been characterised by the dominance of the ruling parties. Following the 2010 and 2014 elections, Fidesz and the KDNP (Fidesz's allied party in Parliament and Government) were able to achieve a two-thirds majority in parliament. A two-thirds pro-government majority provides a stable backdrop for achieving the government's goals. In these political circumstances the opposition, which holds only a third of the seats, cannot gain influence. This fact can also affect the activism and effectiveness of parliament's influence.

In any case, it is evident that the political balance between the executive and the legislative powers is changing in the area of European policy. Parliament, in line with the general European trend, plays a marginalised role in everyday policy-making procedures compared to that of the government. At the same time, it is notable that the Parliament applied the 'yellow card procedure' twice. This clearly indicates the Parliament's ambitions to play a part in influencing decisions of strategic importance. Consequently, the conclusion can be drawn that the Parliament's role is thus limited to addressing strategic issues, points of national sovereignty, rather than the continuous shaping of European policy. 


\section{INTRAGOVERNMENTAL RELATIONS: EUROPEAN AFFAIRS IN THE GOVERNMENT}

As has been discussed with regard to interinstitutional relations, in the division of labour between the powers, the Hungarian experience after accession to the European Union was basically in line with European trends. The intensity of European cooperation put the executive power in a more favourable position than legislation, which is more responsive or reactive in nature. The Hungarian constitutional system, which has established a strong position Government, provided a favourable backdrop to this process. Thus, the role of legislation in European affairs is essentially limited to consultation and the expression of opinion on strategic issues and to lending legitimacy to decisions.

In most countries, a similar process also takes place within the government, i.e. within the executive power. The powers of governments have been extended while those of parliaments have been reduced. At the same time a process of centralisation has also taken place in the government. The increasing significance of central governmental units around the head of government - in Hungary, the Prime Minister's Office - and the rise of the Head of Government is one aspect of the process described as the presidentialisation of the Prime Minister's position. ${ }^{12}$

On the one hand, this means that more and more policy issues are becoming the subject of central government coordination, and the autonomy of ministries is limited by the prime minister's working units intervening in the area of coordination. On the other hand, it means that the Prime Minister stands out from the ranks of ministers, as one who not only coordinates, but in many cases determines individual policy steps. This process is particularly strong in European affairs, where the Prime Minister represents his country on his own at European Council meetings, so that he can take decisions on behalf of his country on his own when taking decisions of strategic importance. ${ }^{13}$

In recent decades, Member States usually use two methods to designate the centre for policy formation in European affairs. The first way, which can be considered more traditional, is when the Ministry of Foreign Affairs is the government unit with the right of coordination in European affairs. The popularity of this approach, which was evidently universal in the initial steps of European integration, is clearly related to the roots of the process: in its first decades, the European Economic Community was formed as an intergovernmental organisation for economic integration, within the framework of the traditional approach to foreign policy.

As the process progressed and European cooperation became ever closer and more inclusive, a new decision-making centre appeared, whereby the prime minister's

12 Fanni Mandák, 'Presidentialisation of Politics and Good Governance in Hungary', in Reflections on Good Governance in Visegrad and Beyond, ed. by Polonca Kovač (Bratislava: NISPAcee Press, 2014), 57-62.

13 Hussein Kassim and Vanessa Buth, 'Europeanization and Member State Institutions', in The Member States of the European Union, ed. by Simon Bulmer and Christian Lequesne (Oxford: Oxford University Press, $3^{\text {rd }}$ edition, 2020), 208. 
coordination unit, the Prime Minister's Office, essentially became the focus of responsibility for European affairs. As integration progresses, the policies which became subjects of EU decision-making procedures gradually leave the realm of traditional foreign policy and increasingly enter the border zone between foreign policy and domestic policy. EU national governments need to make decisions quickly and in a coordinated way in EU decisionmaking. This makes coordination among the government's departments all the more important. To facilitate efficient coordination Prime Minister's Offices have to take over the leading role from Foreign Ministries. This process is also illustrated by the fact that in most Member States the government unit assigned to the Prime Minister now has a coordination centre for European affairs.

In addition to restructuring the political balance between and within institutions, European integration has also had a transformative effect on the institutional systems of the Member States. Certain changes will inevitably occur before membership, during the period of preparation. Examples of these include the emergence of European affairs units in government and legislation. ${ }^{14}$ These bodies were generally institutions with coordinating roles which aimed at developing coordinated national positions on specific policy issues.

In the process of preparing Hungary for EU membership, each ministry set up its own department specialising in European affairs. As negotiations and relations intensified, a need arose to establish a platform for government coordination in European affairs. This new institution for coordination, set up under the influence of the European Union, was the Inter-Departmental Committee for European Coordination, established in 1992. The European Affairs Departments of all the ministries were represented in the Committee. This institutional platform, led by the Ministry of Foreign Affairs, thus comprised a forum where the various ministries could coordinate their positions.

The next steps in the process of becoming a member, carrying out the tasks of the Europe Agreement, which entered into force on 1 February 1994, and submitting the application for accession in April 1994, necessitated the establishment of an even more centralised institutional system. Loose, case-by-case governmental coordination was no longer enough; a centre was needed that could also provide political leadership during the accession process.

For this reason, the State Secretariat for Integration was established in 1996 in the Ministry of Foreign Affairs [Regulation No 64/1996 (V. 3.) Gov. Decree]. The state secretariat became the focus of political leadership in European affairs in the first phase of the accession negotiations. It also integrated the skills and knowledge previously accumulated by various ministries on the issues of European integration accession. The Hungarian institutional system at this stage therefore followed the classic recipe for government coordination

14 Daniela Beyer, 'The neglected effects of Europeanization in the member states - policy-making in directly EU-influenced and sovereign domains', Journal of European Public Policy 25, no 9 (2018), 1299. 
of European affairs by entrusting the Ministry of Foreign Affairs with the coordination and management of European affairs.

Also in 1996, the Parliament adopted the new Regional Development Act (Act XXI of 1996), which was intended to bring Hungarian territorial development policy into line with the regional development policy goals of the European Union. In 1998, further institutions were introduced in regional development policy. The government established regional development regions, which were intended by the then government to eventually become administrative units. Despite serious efforts made by the government to establish such new administrative regions based on the regional development units, this did not come to fruition in the period 2002-2006. The government specifically justified the creation of regional development regions on the grounds that Hungarian development policy and public administration would become Europeanised in this way. ${ }^{15}$

The creation of a special government unit for European affairs is consistent with the experience of other Central European countries. At the beginning of the accession process, each country felt the need to establish, in addition to traditional administrative units, a unit specifically focused on European affairs. ${ }^{16}$ These bodies were not only responsible for the accession negotiations, but also served as a point of communication - an interface - between the European Commission and the government of that country.

By the nature of their activities, these units quickly separated from the rest of the administration and existed as a kind of island within a government that dealt predominantly with domestic issues. This was also the case in Hungary, and this tendency was accentuated by the fact that the State Secretariat for Integration had its seat within the Ministry of Foreign Affairs. It was based within a ministry which, by the nature of its activities, was already separate from the rest of the administration.

The need for better coordination of European affairs and complaints about the preparedness of the Hungarian administration led the government which formed in the summer of 1998 to establish a new unit dealing with the PHARE program and independent in the Prime Minister's Cabinet. This new government structure made political responsibility for pre-accession programs more visible. Under the leadership of a minister without portfolio, the government set up a new office responsible for the PHARE program. This office later extended its activities to all EU funds and became known as the Office for National Development and later the National Development Agency from 2006. While the State Secretariat for Integration was responsible for negotiations with the European Union, the Minister without portfolio in charge of the PHARE program and his office were responsible for EU funds allocated to Hungary. The National Development Agency was

15 Navracsics Tibor, 'Az Országos Területfejlesztési Koncepció országgyülési vitája', in Parlamenti pártok és törvényhozás 1997-1998, ed. by András Lánczi (Budapest: Magyar Politikai Intézet, 1999), 75.

16 Klaus H Goetz, 'The New Member States and the EU: Responding to Europe', in The Member States of the European Union, ed. by Simon Bulmer and Christian Lequesne (Oxford: Oxford University Press, 2005), 272. 
closed in 2014 and the units responsible for EU programs and funds were then integrated into ministries.

Hungary became a member of the European Union on 1 May 2004. However, membership itself does not necessarily lead to institutional changes, since in general, by the final period of accession negotiations, the European Union institutions and the institutions of the acceding country have already established an institutional framework for close cooperation. This was also the case in Hungary. In 2003, however, a minister without portfolio with responsibility for European affairs was appointed for the last phase of the accession negotiations. The former chief negotiator Endre Juhász was in office for less than a year. He left the government in May 2004 to become a judge at the European Court of Justice. He was not replaced by the government for nearly six months.

The minister's seat remained empty until October 2004. The new minister, Etele Baráth, became minister without portfolio in charge of European Affairs from 3 October 2004. He fulfilled this position until June 2006. After his departure the newly elected government abolished this role. The feeling that these developments were the result of improvisation is reinforced by the fact that the tasks of the minister without portfolio were not defined until the end of 2004. It was only then, in Government Regulation No 334/2004 (XII.15.) that the government outlined the minister's powers. Meanwhile, as a result of internal conflicts between the Minister for Economic Affairs and the Minister without a Portfolio for European Affairs over European affairs, the minister without portfolio strengthened his institutional background. ${ }^{17}$

Thus, as the successor to the State Secretariat for Integration of the Ministry of Foreign Affairs, Government Decision No. 356/2004 (XII.23.) established the Office for European Affairs. Simultaneously, the regulation transferred European affairs from the Ministry of Foreign Affairs to the Office of the Prime Minister. In addition to the Office for European Affairs, the regulation also subordinated the Office for National Development to the minister without portfolio. The latter became responsible for the use of EU funds, a decision which clearly confirmed that the minister without portfolio was responsible for shaping European policy.

However, apart from in the period 2003-2006, ministers without portfolios dealing with European affairs have not become a permanent element of the Hungarian government system. In 2006, with the formation of the new government, the position of Minister without Portfolio in Charge of European Affairs was abolished. The governmental coordination of EU affairs was returned to the Ministry of Foreign Affairs. The Department for European Union Affairs, established under the name of The State Secretariat for European Union Affairs, coordinated Hungary's position on EU affairs and the policy positions of various ministries, as well as preparing for the Hungarian Presidency in the first half of 2011.

This institutional setup was not restructured after the change of government in 2010, so until 2014 the coordination of European affairs was carried out under the auspices

17 Brigitta Szabó, 'Kóka-Baráth: első ütközet', Népszabadság, 07 December 2004, 17. 
of the Ministry of Foreign Affairs. The situation changed in 2014, when European affairs were re-transferred to the Prime Minister's Office following the formation of a new government. However, the change in who was responsible for European affairs did not involve a conceptual change. It was, instead, a matter of personal political ambitions. In many cases, a change in the minister's person also paved the way for institutional change. This was the case in 2014, when European affairs were transferred to the Prime Minister simply because of the departure of the former Foreign Minister. In 2019, the new Minister of Justice, who had previously been under-secretary of state for European affairs in the Prime Minister's Office, simply took European affairs with her to her new ministry.

Thus, from 2019 onwards, European affairs were, rather unusually, allocated to the Ministry of Justice. To further complicate matters, from January 2021 a State Secretariat for European Affairs was also established at the Prime Minister's Cabinet Office. This new institution coordinates European affairs specifically for the Prime Minister.

\section{CONCLUSIONS}

This study has traced some of the characteristics of the institutional changes brought about by EU membership through the example of Hungary. As we have seen, over the last 20 years, many institutional changes have happened, most of them related to the accession process or EU membership itself. Others were mainly a matter of personal political aspirations or restructuring. Overall, it can be concluded that while the European Union's impact on the development of the institutional system is undeniable, this drive has not led to uniform patterns in institutional development.

First, regarding interinstitutional equilibrium, there is an unambiguous trend of strengthening the position of the executive at the expense of the legislature. This means that, in terms of the balance of powers, the development of the Hungarian institutional system is entirely in line with the experience of the other Member States of the European Union. The primacy of the executive in the handling of European affairs can clearly be observed. The Hungarian Parliament does not play an important role in shaping political priorities in European affairs. It can only have a more significant transforming effect on European affairs where the EU Treaties explicitly allow it. Instead, its role in the Hungarian constitutional system only extends to supervising the government and obtaining of information on the activities of the government.

Nevertheless, an interesting trajectory emerges for the observer when looking at the development of institutions within the executive power. Prior to 2004, when accession to the European Union was still only a goal and a task of primary importance, it is clear that policy aspects took precedence over other - amongst them party political - aspects. In the early 1990s, units specialised in European affairs were established in the ministries immediately after the first democratic elections. In 1992, an inter-departmental committee coordinating the development of a single government position was also established. This 
tendency is clear-cut and transparent. Moreover, it appears to be universal: it can be compared to other Member States' experience.

However, this is not true for the institutional development at the political level. Unlike the situation at the administrative level, there was a surprisingly high degree of instability in the governance of European affairs over the years. In the first period up to 2003, the Ministry of Foreign Affairs was the government centre for European affairs. This seems similar to the experience of other countries. From 2003 onwards, however, the coordination of European affairs was shifted to a different government unit in each government cycle.

Strangely enough the Prime Minister's Office could not - or did not want to - keep its leading role in the government, in this area. Responsibility for European affairs alternated between the Ministry of Foreign Affairs and the Prime Minister's Office, while recently the Ministry of Justice gained the upper hand. This instability is even more unusual if we take into account that no change in government has taken place in the last eleven years. The frequent and quite inconsistent changes illustrate the fact that institutional changes in Hungary do not happen under the impact of a uniform pattern of Europeanisation, but are based instead on daily political considerations. Consequently, based on the experience of the last 17 years, it can be argued that the location of the government decision-making centre on European affairs depends on which coalition or personal party policy aspects prevail, not on some kind of Europeanisation process.

At the same time, the latest developments seem to support the thesis that European affairs are drawn into the Prime Minister's orbit. Reinforcing the tendency towards the presidentialisation of the Hungarian parliamentary system, the appointment of a new state secretary responsible for the European affairs in the Prime Minister's cabinet gives a good example of this tendency. This means that, from January 2021, the presence of EU affairs in the Prime Minister's environment not only doubles the number of potential decision-making centres in government but can also result in the formal involvement of the highest level in European affairs.

It can be concluded that, rather than being subject to Europeanisation, there has been an institutional adaptation in the government's handling of European affairs in Hungary over the last 20 years. Close policy cooperation does not automatically lead to a single institutional model at EU level. 


\section{REFERENCES}

1. Beyer, Daniela, 'The neglected effects of Europeanization in the member states - policymaking in directly EU-influenced and sovereign domains'. Journal of European Public Policy 25, no 9 (2018), 1294-1316. Online: https://doi.org/10.1080/13501763.2017.1310 275

2. Dezső, Márta and Attila Vincze, Magyar alkotmányosság az európai integrációban. Budapest: HVG-ORAC, 2006.

3. Featherstone, Kevin and Claudio M Radaelli, 'A Conversant Research Agenda', in The Politics of Europeanization, ed. by Kevin Featherstone and Claudio M Radaelli. Oxford: Oxford University Press, 2003. Online: https://doi.org/10.1093/0199252092. 003.0014

4. Goetz, Klaus H, 'The New Member States and the EU: Responding to Europe', in The Member States of the European Union, ed. by Simon Bulmer and Christian Lequesne. Oxford: Oxford University Press, 2005, 254-280.

5. Haas, Ernst B, The Uniting of Europe: Political, Social and Economic Forces 19501957. Stanford: Stanford University Press, $2^{\text {nd }}$ edition, 1968.

6. Kassim, Hussein, 'The Europeanization of Member States Institutions', in The Member States of the European Union, ed. by Simon Bulmer and Christian Lequesne. Oxford: Oxford University Press, 2005, 285-316. Online: https://doi.org/10.1093/hepl/9780198 737391.003.0013

7. Kassim, Hussein and Vanessa Buth, 'Europeanization and Member State Institutions', in The Member States of the European Union, ed. by Simon Bulmer and Christian Lequesne. Oxford: Oxford University Press, $3^{\text {rd }}$ edition, 2020, 301-330. Online: https:// doi.org/10.1093/hepl/9780198737391.003.0013

8. Ladrech, Robert, Europeanization and National Politics. Basingstoke: Palgrave Macmillan, 2010. Online: https://doi.org/10.1007/978-1-137-06814-9

9. Mandák, Fanni, 'Presidentialisation of Politics and Good Governance in Hungary', in Reflections on Good Governance in Visegrad and Beyond, ed. by Polonca Kovač. Bratislava: NISPAcee Press, 2014, 57-62.

10. Milward, Alan, The European Rescue of the Nation-State. Berkeley - Los Angeles: University of California Press, 1992.

11. Mommsen, Hans, 'The Origins of Chancellor Democracy and the Transformation of the German Democratic Paradigm'. German Politics and Society 25, no 2 (2007), 7-18. Online: https://doi.org/10.3167/gps.2007.250202

12. Moravcsik, Andrew, 'Why the European Community Strengthens the State: Domestic Politics and International Cooperation'. CES Working Paper no 52 (1994).

13. Navracsics, Tibor, 'Az Országos Területfejlesztési Koncepció országgyülési vitája', in Parlamenti pártok és törvényhozás 1997-1998, ed. by András Lánczi. Budapest: Magyar Politikai Intézet, 1999, 74-99.

14. Olsen, Johan P, 'The Many Faces of Europeanization', Journal of Common Market Studies 40, no 5 (2002), 921-952. Online: https://doi.org/10.1111/1468-5965.00403 
15. Rometsch, Dietrich and Wolfgang Wessels, 'Conclusion: European Union and National Institutions', in The European Union and Member States: Towards Institutional Fusion? ed. by Dietrich Rometsch and Wolfgang Wessels. Manchester: Manchester University Press, 1996, 328-366.

16. Schiemann, John W, 'Hungary: the emergence of chancellor democracy'. The Journal of Legislative Studies 10, no 2-3 (2004), 128-141. Online: https://doi.org/10.1080/ 1357233042000322265

17. Szabó, Brigitta, 'Kóka-Baráth: első ütközet'. Népszabadság, 07 December 2004.

Tibor Navracsics, $\mathrm{PhD}$, is a Senior Research Fellow and Head of Institute at the University of Public Service, Eötvös József Research Centre, Europe Strategy Research Institute. His research field is European policy. In addition, he is an Honorary Professor at the University of Public Service and an Associate Professor at the Institute of Political Science of the Faculty of Law at Eötvös Loránd University. 